\title{
PENGARUH MOL REBUNG BAMBU DAN KEMATANGAN BOKASHI TERHADAP PERTUMBUHAN DAN HASIL TANAMAN KACANG TANAH (Arachis hypogaea)
}

\author{
Cut Mulia Sari ${ }^{(1)}$, Nazarullah ${ }^{(2)}$ \\ ${ }^{1,2}$ Jurusan Agroteknologi Fakultas Pertanian Universitas Jabal Ghafur, Sigli \\ Email: cutmuliasari@unigha.ac.id
}

\begin{abstract}
ABSTRAK
Penelitian ini bertujuan untuk mengetahui pengaruh mol rebung bambu dan tingkat kematangan bokashi terhadap pertumbuhan dan hasil tanaman kacang tanah (Arachis hypogaea)" serta ada tidaknya interaksi antara kedua faktor yang dicobakan.Penelitian ini dilaksanakan dikebun percobaan Fakultas Pertanian Universitas Jabal Ghafur. Penelitian ini menggunakan Rancangan Acak Kelompok (RAK) pola faktorial 3 x 3 dengan 3 ulangan. Faktor perlakuan mol rebung bambu (M) yaitu: $\mathrm{M}_{1}=75 \mathrm{cc} / \mathrm{liter}$ air, $\mathrm{M}_{2}=150 \mathrm{cc} /$ literair, $\mathrm{M}_{3}=225 \mathrm{cc} / \mathrm{liter}$ air. Faktor pemberian bokasi pemberian yaitu : $\mathrm{B}_{1}=15 \mathrm{~kg} /$ plot, $\mathrm{B}_{2}=30 \mathrm{~kg} / \mathrm{plot}, \mathrm{B}_{3}=45 \mathrm{~kg} / \mathrm{plot}$. Parameter yang diamati pada komponen tanaman jagung meliputi : tinggi tanaman (umur 15, 30 dan 45 HST), jumlah polong dalam satu tanaman dan berat polong/plot (kg). Hasil penelitian menunjukan bahwa, pemberian mol rebung bambu tidak berpengaruh nyata terhadap semua pengamatan yang sudah dicobakan. Pemberian bokashi berpengaruh sangat nyata terhadap parameter tinggi tanaman kacang tanah pada umur 15 HST, dan tidak berpengaruh nyata terhadap parameter lainnya pada umur 30 HST dan 45 HST. Perlakuan terbaik di jumpai $\mathrm{B}_{1}(15$ $\mathrm{kg} / \mathrm{plot}$ ). Tidak terdapat interaksi yang nyata antara pemberian mol rebung bambu dan tingkat kematangan bokashi terhadap semua pengamatan diamati.
\end{abstract}

Kata kunci : Mol Rebung Bambu, Kematangan Bokhasi, Tanaman Kacang Tanah

\section{PENDAHULUAN}

Kacang tanah (Arachis hypogaea) merupakan tanaman loguminoceae. Tanaman ini berasal dari Amerika Selatan tepatnya adalah Brazillia, namun saat ini telah menyebar ke seluruh dunia yang beriklim tropis atau subtropis. Masuknya kacang tanah ke Indonesia pada abad ke-17 diperkirakan karena dibawa oleh pedagang-pedagang Spanyol,Cina,atau Portugis sewaktu melakukan pelayarannya dari Meksiko ke Maluku setelah tahun 1597 Pada tahun 1863 Holle memasukkan Kacang Tanah dari Inggris dan pada tahun 1864 Scheffer memasukkan pula Kacang Tanah dari Mesir Republik Rakyat Cina dan India kini merupakan penghasil kacang tanah terbesar dunia. Di Indonesia kacang tanah terpusat di Pulau Jawa, Sumatra Utara, Sulawesi dan kini telah ditanam di seluruh Indonesia. Tanaman Kacang tanah bisa dimanfaatkan untuk makanan ternak, sedang bijinya dimanfaatkan sebagai sumber protein nabati, minyak dan lain-lain (Suprapto, 2000).

Mengingat begitu banyaknya manfaat yang ada pada kacang tanah, berkorelasi positif terhadap pembudidayaannya. Di Indonesia kacang tanah sudah banyak dibudidayakan namun produksi komoditi kacang tanah per hektar belum mencapai hasil maksimum, beberapa faktor penyebab terjadinya hal tersebut antara lain pengaruh tanah yang semakin rusak, kurangnya 
ketersediaan unsur hara terutama unsur hara mikro serta hormon pertumbuhan. Selain itu juga karena faktor hama dan penyakit tanaman, iklim, serta aspek pemeliharaan lainnya (Agrista, 2013).

Dalam meningkatkan produksi penting juga dianjurkan untuk tetap menjaga kelestarian lingkungan supaya lingkungan tetap lestari. Untuk mengantisipasi masalah tersebut perlu didukung oleh benih yang unggul dan teknik pemeliharaan nya tepat. Penanaman yang dikelola dengan baik diharapkan dapat menghasilkan pertumbuhan tanaman yang sehat dan mempunyai sistem perakaran yang kuat sehingga dapat mengambil unsur hara (nutrisi) dari dalam tanah dengan sempurna.

Mikroorganisme Lokal (MOL) adalah mikroorganisme yang dimanfaatkan sebagai starter dalam pembuatan pupuk organik padat maupun pupuk cair. Larutan mol adalah cairan yang mengandung mikroorganisme hasil produksi sendiri dari bahan-bahan alami disekeliling kita, dimana bahan-bahan tersebut tempat yang sebagai media untuk hidup dan berkembangnya mikroorganisme yang berguna dalam mempercepat penghancuran bahan-bahan organik (decomposer) dan dapat menambah nutrisi bagi tanaman (Setianingsih, 2009). Secara umum, pemanfaatan MOL salah satu upaya meningkatkan kemandirian petani. Beberapa jenis larutan MOL yang telah diaplikasikan oleh petani dibeberapa daerah antara lain : (1)MOL buah-buahan yang diaplikasikan pada tanaman sebagai pupuk dan dekomposer dalam pembuatan kompos. (2)MOL daun cebreng untuk penyubur daun tanaman. (3)MOL bonggol pisang untuk dekomposer saat pembuatan kompos. (4)MOL sayuran yang disemprotkan pada tanaman padi. (5)MOL rebung bambu untuk merangsang pertumbuhan tanaman.
Pupuk bokashi adalah pupuk organik (dari bahan jerami, pupuk kandang, sampah organik, dll) hasil fermentasi dengan teknologi EM-4. Pembuatannya juga tidak rumit, karena menggunakan bahan-bahan yang mudah didapat dan tidak perlu memerlukan alat yang canggih, hanya cukup secara konvensional. Pembuatan bokashi dikatakan berhasil jika bahan bokashi terfermentasi dengan baik yaitu akan ditumbuhi oleh jamur yang berwarna putih dan aromanya sedap. Sedangkan jika dihasilkan bokashi yang berbau busuk, maka pembuatan bokashi gagal. Jika bokashi sudah jadi sebaiknya langsung digunakan. Namun jika bokashi ingin disimpan terlebih dahulu, maka bokashi harus dikeringkan terlebih dahulu dengan cara menganginanginkan di atas lantai hingga kering. Setelah kering bokashi dapat dikemas didalam kantung plastik (Musnamar, 2003).

\section{METODOLOGI}

Penelitian dilaksanakan di Kebun Percobaan Fakultas Pertanian Universitas Jabal Ghafur. Penelitian ini menggunakan Rancanagan Acak Kelompok (RAK) pola faktorial, yang terdiri dari 2 faktor yaitu faktor pertama perlakuan mol rebung bambu (M) yang terdiri dari 3 taraf dan faktor kedua kematangan bokashi (B) yang terdiri 3 taraf perlakuan.

Faktor perlakuan mol rebung bambu (M) yaitu:

$$
\begin{aligned}
& M_{1}=75 \mathrm{cc} / \text { liter air } \\
& M_{2}=150 \mathrm{cc} / \text { liter air } \\
& \mathrm{M}_{3}=225 \mathrm{cc} / \mathrm{liter} \text { air }
\end{aligned}
$$

Faktor pemberian bokasi pemberian yaitu :

$$
\begin{aligned}
& \mathrm{B}_{1}=15 \mathrm{~kg} / \mathrm{plot} \\
& \mathrm{B}_{2}=30 \mathrm{~kg} / \mathrm{plot} \\
& \mathrm{B}_{3}=45 \mathrm{~kg} / \mathrm{plot}
\end{aligned}
$$

Dengan demikian terdapat 9 kombinasi perlakuan dan 3 ulangan. Sehingga secara keseluruhan diperoleh 27 satuan percobaan. 
Jurnal Sosial Humaniora Sigli (JSH)

p ISSN : 2615-3688

$e$ ISSN : 2716-0270

http://journal.unigha.ac.id/index.php/JSH

\section{Tabel 1. Susunan Kombinasi Perlakuan Antara Mol Rebung Bambu dengan Kematangan Bokashi.}

\begin{tabular}{|c|c|c|c|}
\hline No. & $\begin{array}{l}\text { Kombinasi } \\
\text { Perlakuan }\end{array}$ & $\begin{array}{l}\text { Perlakuan Mol } \\
\text { rebung bambu } \\
\text { (cc/Liter air) }\end{array}$ & $\begin{array}{c}\text { Tingkat } \\
\text { kematanga } \\
\mathrm{n} \text { bokashi } \\
(\mathrm{kg} / \mathrm{plot})\end{array}$ \\
\hline 1. & $\mathrm{M}_{1} \mathrm{~B}_{1}$ & 75 & 15 \\
\hline 2. & $\mathrm{M}_{1} \mathrm{~B}_{2}$ & 75 & 30 \\
\hline 3. & $\mathrm{M}_{1} \mathrm{~B}_{3}$ & 75 & 45 \\
\hline 4. & $\mathrm{M}_{2} \mathrm{~B}_{1}$ & 150 & 15 \\
\hline 5. & $\mathrm{M}_{2} \mathrm{~B}_{2}$ & 150 & 30 \\
\hline 6. & $\mathrm{M}_{2} \mathrm{~B}_{3}$ & 150 & 45 \\
\hline 7. & $\mathrm{M}_{3} \mathrm{~B}_{1}$ & 225 & 15 \\
\hline 8. & $\mathrm{M}_{3} \mathrm{~B}_{2}$ & 225 & 30 \\
\hline 9. & $\mathrm{M}_{3} \mathrm{~B}_{3}$ & 225 & 45 \\
\hline
\end{tabular}

\section{Pelaksanaan Penelitian}

\section{Persiapan Lahan dan Pengolahan Tanah}

Pola tanam memperhatikan musim dan curah hujan. Pada tanah yang subur, untuk membuat plot-plot percobaan, areal dibagi menjadi 2 kelompok dan setiap kelompok terdapat 16 plot percobaan. Plot percobaan berukuran $150 \mathrm{~cm} \times 100 \mathrm{~cm}$ dengan jarak antar plot $40 \mathrm{~cm}$ dan antar ulangan $50 \mathrm{~cm}$.

Tanah diolah dengan cara konvensional yaitu diolah dengan cara sempurna. Plot dibuat dengan ukuran panjang $150 \mathrm{~cm} \times 100 \mathrm{~cm}$ dengan jarak antar plot $40 \mathrm{~cm}$ dan antar ulangan $50 \mathrm{~cm}$.

\section{Penanaman}

Penanaman dilakukan dengan menungal sedalam $3 \mathrm{~cm}$ dengan jarak tanam $20 \mathrm{~cm} \times 20 \mathrm{~cm}$. setiap lubang tanam diisi 2 butir benih kacang tanah kemudian ditutup kembali dengan menggunakan tanah yang gembur dan subur.

\section{Aplikasi Mol Rebung Bambu}

Pemberian mol rebung bambu diberikan pada bokasi yang tingkat kematangannya 15 hari,30 dan 40 hari. Dengan cara air mol rebung bambu tersebut disiran diatas permukaan bokashi yang difermentasikan guna sebagai penganti $\mathrm{EM}_{4}$.

\section{Cara Pemberian Bokashi}

Bokashi yang siap untuk diaplikasikan pada tanaman yaitu pada tingkat kematangan bokashi pada umur 15 hari, 30 hari dan 45 hari.

\section{Pemeliharaan Tanaman}

Pemeliharaan tanaman terdiri dari penyiraman, penyiangan dan pengenda-lian gulma. Penyiraman dilakukan pembumbunan dengan tujuan untuk memperbaiki struktur tanah sehingga poripori tanah dapat dilalui oleh air dan udara serta ginofornya dapat berkembang baik dan mampu menembus tanah. Penyiangan dilakukan 2 kali umur 1 dan 6 minggu dengan hati-hati agar tidak merusak bunga dan polong. Pembumbunan dilakukan bersamaan saat penyiangan, bertujuan untuk menutup bagian perakaran. Pengairan dilakukan agar tanah tetap lembab. Pemeliharaan lain meliputi hal- hal yang sangat menunjang faktor pemeliharaan bisa dilakukan, misalnya pemangkasan, perambatan, pemeliharaan tunas dan bunga serta sanitasi lingkungan lahan (dijaga agar menunjang kesehatan tanaman).

\section{Pengamatan}

a. Tinggi Tanaman $(\mathrm{cm})$

Tinggi tanaman diukur pada umur 15, 30 dan 45 HST. Tinggi yang diukur dari leher akar sampai titik tumbuh tertinggi.

b. Jumlah Polong dalam satu tanaman

Jumlah polong dalam satu tanaman di hitung pada saat melakukan pemanenan. Dihitung berdasarkan hasil panen pertama sampai panen ke lima,kemudian dijumlahkan.

c. Berat Polong per plot $(\mathrm{kg})$

Berat polong per plot ditimbang pada saat melakukan pemanenan yaitu pada umur 3 bulan setelah tanam. 
Jurnal Sosial Humaniora Sigli (JSH)

p ISSN : 2615-3688

$e$ ISSN : 2716-0270

http://journal.unigha.ac.id/index.php/JSH

HASIL DAN PEMBAHASAN

Pengaruh Pemberian Mol Rebung

Bambu

Tinggi Tanaman

Hasil pengamatan menunjukkan bahwa, jenis pemberian mol rebung bambu tidak berpengaruh nyata terhadap tinggi tanaman pada umur 15, 30, dan 45 HST. Selanjutnya rata-rata tinggi tanaman kacang tanahumur 15, 30 dan 45 HST dapat dilihat Tabel 2.

Tabel 2. Rata-rata Tinggi Tanaman Kacang Tanah Umur 15, 30 dan 45 HST Akibat Pengaruh Pemberian Mol Rebung Bambu

\begin{tabular}{cccc}
\hline \multirow{2}{*}{$\begin{array}{c}\text { Mol Rebung } \\
\text { Bambu }\end{array}$} & \multicolumn{3}{c}{ Tinggi Tanaman $(\mathrm{cm})$} \\
\cline { 2 - 4 } & $15 \mathrm{HST}$ & $30 \mathrm{HST}$ & $45 \mathrm{HST}$ \\
\hline $\mathrm{M}_{1}$ & 15,44 & 37,11 & 59,07 \\
$\mathrm{M}_{2}$ & 14,88 & 37,14 & 59,51 \\
$\mathrm{M}_{3}$ & 14,73 & 37,33 & 59,25 \\
\hline
\end{tabular}

Dari data pada Tabel 2 dapat dilihat bahwa,rata-rata tinggi tanaman kacang tanah pada umur 15,30 dan 45 HST yang tertinggi akibat pengaruh mol rebung bambu masing - masing dijumpai pada perlakuan $\mathrm{M}_{1}=$ $15,44 \mathrm{~cm}, \mathbf{M}_{3}=37,33 \mathrm{~cm}$ dan $\mathbf{M}_{2}=59,51$ $\mathrm{cm}$. Sedangkan rata-rata tinggi tanaman kacang tanah yang terendah akibat pengaruh mol rebung bambu masing-masing dijumpai pada perlakuan $\mathrm{M}_{3}=15,18 \mathrm{~cm}, \mathrm{M}_{1}=37,11$ $\mathrm{cm}$ dan $\mathrm{M}_{1}=59,07 \mathrm{~cm}$. Menurut Ibrahim (2002, Tanaman mencapai tingkat pertumbuhan bila unsur hara yang dibutuhkan tanaman berada dalam keadaan cukup tersedia unsur $\mathrm{N}, \mathrm{P}$ dan $\mathrm{K}$ sehingga tanah akan mempengaruhi pertumbuhan dan produksi tanaman tersebut.

\section{Jumlah Polong Kacang}

Hasil pengamatan menunjukkan bahwa, jenis pemberian mol rebung bambu tidak berpengaruh nyata terhadap Jumlah Polong. Rata-rata jumlah polong kacang Tabel 3.
Tabel 3. Rata-rata Jumlah Polong Kacang Tanah dalam Satu Tanaman Akibat Mol Rebung Bambu

\begin{tabular}{cc}
\hline $\begin{array}{c}\text { Mol Rebung } \\
\text { Bambu }\end{array}$ & $\begin{array}{c}\text { Jumlah Polong ( buah } \\
\text { ) }\end{array}$ \\
\hline $\mathrm{M}_{1}$ & 14,47 \\
$\mathrm{M}_{2}$ & 14,40 \\
$\mathrm{M}_{3}$ & 14,70 \\
\hline
\end{tabular}

Dari data pada Tabel3 dapat dilihat bahwa, rata -rata jumlah polong tanaman kacang tanah dalam satu tanaman akibat pemberian mol rebung bambu yang tertinggi dijumpai pada perlakuan $\mathrm{M}_{3}$ yaitu 14,70 buah. Sedangkan rata-rata jumlah polong kacang tanah akibat pemberian mol rebung bambu yang terendah di jumpai pada perlakuan $\mathrm{M}_{2}$ yaitu 14,40 buah.

Kandungan unsur hara terutama posfat yang tinggi dapat memicu pertumuhan buah yang banyak, disebabkan karena unsur hara $\mathrm{P}$ memiliki peran yang sangat penting untuk merangsang pertumbuhan buah (Bidwell, 1997).

\section{Berat Polong Per Plot}

Hasil Analisis Ragam menunjukkan bahwa pengaruh pemberian mol rebung bambu tidak berpengaruh nyata terhadap berat polong perplot tanaman kacang tanah. Selanjutnya rata-rata Berat polong perplot tanaman kacang tanah dapat dilihat Tabel 4.

\section{Tabel 4. Rata-rata Berat Polong / Plot Tanaman Kacang Tanah Akibat Mol Rebung Bambu}

\begin{tabular}{cc}
\hline $\begin{array}{c}\text { Mol Rebung } \\
\text { Bambu }\end{array}$ & $\begin{array}{c}\text { Berat Polong per plot } \\
(\mathrm{Kg})\end{array}$ \\
\hline $\mathrm{M}_{1}$ & 2,51 \\
$\mathrm{M}_{2}$ & 2,38 \\
$\mathrm{M}_{3}$ & 2,28 \\
\hline
\end{tabular}

Dari data tabel 4 dapat dilihat bahwa,rata - rata berat polong perplot tanamankacang tanah akibat pemberian mol rebung bambu yang tertinggi dijumpai pada perlakuan $\mathrm{M}_{1}$ yaitu $2,51 \mathrm{~kg}$. Sedangkan rata- 
rata berat polong perplot yang terkecil di jumpai pada perlakuan pada perlakuan $\mathrm{M}_{3}$ yaitu $2,28 \mathrm{~kg}$.

Kandungan nitrogen dan fosfat yang kurang dar ibatas minimum dalam pupuk organic cair tidak akan berdampak pada pertumbuhan, perkembangan serta produksi tanaman kacang tanah (Sundari, 2012).

\section{Pengaruh Tingkat Kematangan Bokashi Tinggi Tanaman}

Hasil pengamatan menunjukkan bahwa, jenis kematangan bokhasi berpengaruh sangat nyata terhadap tinggi tanaman pada umur 15 HST dan berpengaruh nyata pada umur 30, dan 45 HST. Selanjutnya rata-rata tinggi tanaman kacang tanah umur 15, 30 dan 45 HST dapat dilihat Tabel 5.

Tabel 5. Rata-rata Tinggi Tanaman Kacang Tanah Umur 15, 30 dan 45 HST Akibat Pengaruh Tingkat Kematangan

\begin{tabular}{cccc}
\multicolumn{4}{c}{ Bokashi } \\
\hline \hline Tingkat & \multicolumn{3}{c}{ Tinggi Tanaman $(\mathrm{cm})$} \\
\cline { 2 - 4 } Kematangan & & & \\
Bokashi & $15 \mathrm{HST}$ & $30 \mathrm{HST}$ & $45 \mathrm{HST}$ \\
\hline $\mathrm{B}_{1}$ & $14,22^{\mathrm{a}}$ & 37,55 & 59,96 \\
$\mathrm{~B}_{2}$ & $15,44^{\mathrm{b}}$ & 36,96 & 58,99 \\
$\mathrm{~B}_{3}$ & $15,40^{\mathrm{b}}$ & 37,33 & 58,88 \\
\hline BNJ 0,05 & 3,04 & & \\
\hline \hline
\end{tabular}

Keterangan : Angka yang diikuti huruf yang sama pada kolom yang sama tidak berbeda nyata pada taraf $\alpha=5 \%$ (Uji BNJ)

Dari Tabel 5 dapat dijelaskan bahwa, rata -rata tinggi tanaman kacang tanah umur 15 HST akibat pengaruh tingkat kematangan bokashi yang tertinggi di jumpai pada perlakuan $\mathrm{B}_{1}$ yaitu $14,22 \mathrm{~cm}$. Sedangkan rata -rata tinggi tanaman kacang tanah umur 15 HST akibat pengaruh tingkat kematangan bokashi yang terendah di jumpai pada perlakuan $B_{3}$ yaitu $15,40 \mathrm{~cm}$.

Pada tinggi tanaman umur 15 hari HST terlihat jelas secara fisik bahwa jenis bokashi mempengaruhi awal pertumbuhan vegetativ tanaman, hal ini di duga bahwa bokashi mampu menyediakan unsur hara bagi tanaman walaupun dalam jumlah yang sedikit untuk meningkatkan pertumbuhan tanaman (Anonim, 2013).

\section{Jumlah Polong Kacang}

Hasil pengamatan (Lampiran 8) menunjukan bahwa pemberian mol rebung bambu tidak berpengaruh nyata terhadap Parameter jumlah polong kacang. Selanjutnya rata-rata jumlah polong kacang tanah dalam satu tanaman dapat dilihat Tabel 6.

Tabel 6. Rata-rata Jumlah Polong Kacang Tanah dalam Satu Tanaman Akibat Tingkat Kematangan Bokashi

\begin{tabular}{cc}
\hline \hline $\begin{array}{c}\text { Tingkat } \\
\text { Kematangan } \\
\text { Bokashi }\end{array}$ & $\begin{array}{c}\text { Jumlah Polong } \\
\text { (buah) }\end{array}$ \\
\hline B $_{1}$ & 14,73 \\
$\mathrm{~B}_{2}$ & 14,47 \\
$\mathrm{~B}_{3}$ & 14,36 \\
\hline
\end{tabular}

Dari data pada Tabel 6 dapat dilihat bahwa, rata -rata jumlah polong tanaman kacang tanah akibat pengaruhtingkat kematangan bokashiyang tertinggi dijumpai pada perlakuan $\mathrm{B}_{3}$ yaitu 14,73 buah. Sedangkan rata-rata jumlah polong terkecil dijumpai pada perlakuan akibat pengaruh tingkat kematangan bokashi pada perlakuan $\mathrm{B}_{3}$ yaitu 14,22 buah.

Hal ini disebabkan oleh unsur hara yang terdapat dalam bokashi tidak dapat di serap langsung oleh tanaman sehingga membutuhkan waktu dekomposisi lebih lama secara sempurna agar unsur hara yang terdapat di dalam nya tersedia bagi tanaman(Sauwibi, 2012).

\section{Berat Polong Per Plot}

Hasil Analisis Ragam menunjukkan bahwa pengaruh pemberian mol rebung bambu tidak berpengaruh nyata terhadap berat polong per plot tanaman kacang tanah. Selanjutnya rata-rata Berat polong per plot tanaman kacang tanah dapat dilihat Tabel 7. 
Jurnal Sosial Humaniora Sigli (JSH)

p ISSN : 2615-3688

$e$ ISSN : 2716-0270

http://journal.unigha.ac.id/index.php/JSH

Tabel 7. Rata-rata Berat Polong / Plot Tanaman Kacang Tanah Akibat Pengaruh Tingkat Kematangan Bokashi

\begin{tabular}{cc}
\hline \hline $\begin{array}{c}\text { Tingkat } \\
\text { Kematangan } \\
\text { Bokashi }\end{array}$ & $\begin{array}{c}\text { Berat Polong per } \\
\text { plot (Kg) }\end{array}$ \\
\hline $\mathrm{B}_{1}$ & 2,52 \\
$\mathrm{~B}_{2}$ & 2,24 \\
$\mathrm{~B}_{3}$ & 2,40 \\
\hline
\end{tabular}

Dari data Tabel 7 dapat dilihat bahwa,rata - rata berat polong perplot tanaman kacang tanah akibat pengaruh tingkat kematangan bokashi yang tertinggi dijumpai pada perlakuan $\mathrm{B}_{1}$ yaitu $2,52 \mathrm{~kg}$. Sedangkan rata-rata berat polong per plot terkecil di jumpai pada perlakuan pada perlakuan $\mathrm{B}_{2}$ yaitu $2,24 \mathrm{~kg}$.

Pembuatan bokashi dengan teknologi EM4 sangat menguntungkan bagi tanaman karena dapat meningkatkan hasil produksi tanaman.Pembuatan bokashi sangat efektif dan efisien bagi petani karena mudah, murah, ramah lingkungan dan dapat memberikan hasil yang maksimal (Hadiwiyoto, 1993).

\section{SIMPULAN}

1. Hasil pengamatan menunjukkan bahwa mol rebung bambu tidak berpengaruh nyata pada semua perlakuan pada umur 15, 30 dan 45 HST.

2. Perlakuan tingkat kematangan bokashi berpengaruh sangat nyata terhadap tinggi tanaman umur 15 HST. Dan tidak berpengaruh nyata pada umur 30 HST dan 45 HST.

3. Terdapat interaksi yang nyata dan tidak nyata antara mol rebung bambu dan tingkat kematangan bokashi.

DAFTAR PUSTAKA

Suprapto.2000. kacang Tanah dan Manfaatnya. Penebar Swadaya. Jakarta.
Agrista. 2013. Sayuran Jepang. Penebar Swadaya, Jakarta.

Setianingsih. 2009. Pestisida Alami. http//www.jurnal-online.um.ac.id [ Oktober 2017

Musnamar. 2003. Kacang Tanah. Penebar Swadaya. Jakarta.

Ibrahim. 2002. Intergrasi Jenis Tanaman Pohon Leguminosa Dalam Sistem Budidaya Lahan Kering dan Pengaruhnya Terhadap Sifar Tanah, Erosi dan Produktivitas Tanah. Makasar.

Bidwell.1997. Bertanam Kacang Tanah Secara Komersial. Penerbit Penebar Swadaya, Jakarta.

Sundari. 2012. Hama dan Penyakit Tanaman Semusim. Penebar Swadaya. Jakarta.

Sauwibi. 2012. Manfaat dan Cara pembuatan Mol Buah, Gremadia Pustaka. Jakarta. 